\title{
GENETICALLY IMPROVEMENT OF SOME PERFORMANCE TRAITS OF EGYPTION LOCAL CHIKENS BY TRANSFERRING GROWTH HORMONE GENE FROM BROILER
} W. S. EL-Tahawy; ${ }^{1}$ Ghanem H.H.; ${ }^{2}$ A.N.Nawar ${ }^{2}$ and Ebrahim. A. Sabra ${ }^{3}$

${ }^{1}$ Anim. and Poult. Prod. Dep., Fac. of Agric., Damanhour Uni., Egypt

${ }^{2}$ Anim. Prod. Res. Inst., Agric. Res. Center, Giza, Egypt

${ }^{3}$ Anim. Biotechn. Dep., Genetic Engin.and Biotechn. Res. Inst.,Uni. of Sadat City, Egypt

Corresponding author: Waleed salah EL-Tahawy;E mail:waleed.eltahawy@agr.dmu.edu.eg

Received: $12 / 05 / 2021 \quad$ Accepted: $07 / 06 / 2021$

\begin{abstract}
The present study was aimed to investigate isolation, cloning and sequencing of chicken Growth hormone gene (cGH) from chicken (cobb 500 broilers) then transfer chicken Growth hormone gene by two methods the first gene transfer method by using sperm-mediated gene transfer (SMGT) technique and the second gene transfer method using bioresonance (Bio) to local chicken strain (Bandarah). This study was investigate for two generation. The body weight at hatch and 4 weeks of age increased by 3.32 and $8.09 \mathrm{~g}$ for SMGT method and by 1.27 and 5.22g for Bio method respectively. The SMGT method was increased the body weight at $12 \mathrm{wk}$ of age by 60.17 and $7.96 \mathrm{~g}$ for males and females respectively. The growth rate during 0-4 weeks of age was $131.64,130.68$ and $132.35 \%$, for SMGT, Bio and control respectively.

In conclusion cGH Gene successfully isolate, molecular cloning from Cobb 500 and transferring by two methods SMGT and Bio to produce transgenic chickens of a local strain in Egypt .SMGT is an efficient method that will hopefully facilitate the implementation of strategies for securing the benefits that can be expected to arise from the introduction of transgenic chicken, Bio open important new perspectives in the field of animal transgenic would be more rapid, with quick and effective delivery of genes to target tissues. Chicken $\mathrm{cGH}$ gene was effect in all growth traits and moved from the first generation to the second generation with the same shape and increased the effect. The second generation gave higher body weight at $0,4,8$ and 12 weeks of age.
\end{abstract}

Key words: Local chicken, cGH gene, Gene transfer, SMGT, Growth traits 


\section{INTRODUCTION}

In recent years, the most advanced research in the world has been the genetically modified technology. The manipulation of animal genome has offered a powerful bioreactor for the production of pharmaceutical and industrial proteins ( $\mathrm{Li}$ and $\mathrm{Lu}, 2010$ ).

Development of simple and readily adoptable methods to mediate gremlin engineering of the chicken genome will have many applications in research, agriculture and industrial biotechnology (Challagulla et al., 2020). Specific developmental characteristics of the chicken make it an attractive model for the generation of transgenic organisms. Several transgenic chickens have been generated during the last two decades via viral and non-viral transfection.

The new approaches and technologies can be applied to generate a transgenic chicken with regards to recombinant protein productions (Bahrami et al., 2020). Growth trait is very important economic trait in broiler production, and is controlled by complex genes. Chicken growth hormone (cGH) consists of 4,101 base pairs, having five exons and four introns (Kansaku et al., 2008), and containing 191 amino acid residues (Hrabia et al., 2008). Hormones such as the growth hormone, IGF, thyroid hormones and insulin, play important and diverse roles in animal growth (Zhou et al., 2005). Most of the functions of the growth hormone in chickens are mediated by insulin-like growth factors (IGF) which stimulate amino acid uptake, glucose metabolism, DNA synthesis (McMurtry, 1998), protein synthesis, and the proliferation of different cell types (McMurtry et al., 1997). Recombinant DNA technology is another major DNA- based tool that has gained popular attention in the past decade. This technology allows scientists to find individual genes, cut them out, and insert them into the genome of another organism. The gene transfer technology has been applied by different methods that includes Microinjection, Sperm-mediated cell, Retroviral vectors, Primordial germ cells and Plasmid as vectors. A logical alternative strategy to generate transgenic animals theoretically consists of the introduction of foreign DNA into male gametes before the fertilization process (Spadafora., 2002). As a result of Bioresonance Therapy, a weakened organ receives energy needed for normal functioning, which is redistributed on a wide scale, restoring the workability of affected organs. Thousands of people have been able to cut down on their dosages of medicines, and in some cases have entirely stopped taking them and have regained excellent health. (WHO 2015).Poultry production is an important and diverse component of agriculture all over the world. Meat from native chickens is preferred by more Thai consumers than commercial broilers due to their superior taste and meat texture. However, the native chickens are inferior in production due to their low growth rates, as compared with commercial breed production. (Promwatee, et al., 2013).

The objective of this study was genetic improvement of some performance traits of local chicken (Bandarah) strain by isolate, molecular cloning, sequencing and transferring of GH Gene from Cobb 500, by two methods of gene transfer the first one gene transfer using Sperm Mediated Gene Transfer (SMGT) and the second method gene transfer using Bioresonance (Bio). 


\section{MATERIALS AND M ETHODS}

The present study was carried out at Faculty of Agriculture Damanhour University Animal and Poultry Production Department and El-Sabahia Poultry Research Station Alexandria, Animal Production Research Institute, Agricultural Research Center, Ministry of Agriculture. With the cooperation of Genetic Engineering and Biotechnology Research Institute (GEBRI), University of Sadat City, Egypt and BioMedTec, University of Lübeck, Germany from 2017 to 2019. Bandarah strain was used in this experimental. Bandarah was develop chicken strain could be utilized as foundation stock for meat production (Mahmoud et al., 1989).

\section{Experimental birds and treatments:}

A total 125 hens and 25 cocks at 8 month of age of Bandrah chicken strain were used to start this study to produce generation one table (1). The birds were assigned in individual cages; feed and water provided ad-libitum and divided randomly into 3 groups. Group A used method cGH gene transfer using sperm-mediated cell technique contain 50 hens and 10 cocks, group B used method cGH gene transfer using bioresonance contain 50 hens and 10 cocks, group $\mathrm{C}$ control group used classic artificial insemination contain 25 hens and 5 cocks. Second generation was done by classic artificial insemination between cocks and hens from each group. First group SMCT taking $2 \mathrm{~mL}$ of mixed solution contains $1 \mathrm{~mL}$ of semen $10 \mu \mathrm{g}$ dose of $\mathrm{cGH}$ gene, Lipofectin reagent and saline, second group taking 2 $\mathrm{mL}$ of mixed solution contains $1 \mathrm{~mL}$ of semen which treat by Bioresonance method, Lipofectin reagent and saline and third group taking $2 \mathrm{~mL}$ of mixed solution contains $1 \mathrm{~mL}$ of semen without any gene treatment, Lipofectin reagent and saline used in dilution.

\section{Molecular isolation and cloning Growth hormone gene: Chicken liver samples:}

Liver samples were immediately excised from chicken fast growing (cobb500 broilers) as a high producing exotic broiler strain at 3 weeks age. The collected liver tissue was rapidly dissected into small pieces using sterile scalpel, immediately stored at $-80^{\circ} \mathrm{C}$ until RNA extraction.

Total RNA extraction and cDNAsynthesis :

Total RNA was extracted from the liver sample using RNA-spin ${ }^{\mathrm{TM}}$ Total RNA Extraction Kits (iNtRON Biotechnology, Inc) following manufacturer's recommendations. RNA was quantified using Nano Drop technology with the Epoch Multi-Volume Spectrophotometer System (Biotech, Winooski, VT, USA).

Amplification of chicken growth hormone (cGH) cDNA by reverse transcriptase polymerase chain reaction (RT-PCR):

One microgram of each total RNA was reverse transcribed using Superscript II reverse transcriptase (Life Technologies, Inc., Grand Island, NY) according to the manufacturer's directions. A $0.1-\mathrm{ml}$ aliquot of the reaction was used in each PCR, using specific primers for GH. The forward primers located in exons 1 (PE1F) and 4 (PE4F) of the chicken GH $(\mathrm{cGH})$ gene were TCAAGCAACACCTGAGCAACTC and TTTTGGCACCTCAGACAGAGTG, respectively, and the reverse $\mathrm{GH}$ primer located in exon 5 (PE5R) was CTGTGGGTTTATTCCTCGTGT. PCR was carried out using TAKARA TaqDNA polymerase (TAKARA, Otsu, Japan) and a thermal cycler (Gene Amp 
PCR System 9700, PE Applied Biosystems, Foster City, CA). The temperature cycling conditions for the PCR were 35 cycles of reactions including denaturation for $30 \mathrm{sec}$ at $95{ }^{\circ} \mathrm{C}$ and extension for 1 min at $60{ }^{\circ} \mathrm{C}$, followed by additional extension for $10 \mathrm{~min}$ at $60{ }^{\circ} \mathrm{C}$. A $10 \mu \mathrm{La}$ liquot of each resulting reaction was electrophoresed on a 2.0\% agarose gel, stained with ethidium bromide, and photographed under UV illumination. The amplified cDNA fragments were then sub cloned into a pGEM3Zf + plasmid and subjected to sequencing. DNA sequencing was performed using fluorescent primers and an automated DNA sequence (PE Applied Biosystems 373A).

cGH gene transfer methods:

The first method was using spermmediated gene transfer:

The foreign GH gene was transferred using sperm-mediated gene transfer. The role of the spermatozoa during fertilization is to transfer a haploid genome to the resultant zygote. This capacity has been exploited as an innovative strategy for the delivery of exogenous DNA for the production of transgenic animals (Lauria and Gandolfi., 1993 and Kim et al., 1997).

The second method was using Bioresonance:

The broiler cobb 500 blood sample insert inside a magnetic coil targeting the specific gene growth hormone $(\mathrm{GH})$, mRNA with a special software to be stored as a magnetic pattern same like sampling a sound file on a disk the transmitting this pattern to the Bandarah chicken semen with the same technique. (Mohammad et al. 2015).

\section{Birds and their management:}

Chicks hatched from different experimental groups of artificial insemination experiments were kept under similar hygienic and environmental conditions.
Hatched chicks Vaccination and medication were done according to the used program in the station, as follows: Marick disease at hatch ,Hitchener B1 + (IB) ( Spraying at 7 day, Gumboro at12 day, Lasota at 18 day, Gumboro at 24 day, Avian influenzaInjection at 32 day, Lasota + IB (Spraying) at 40 day, Fowl Pox at 50 day and Lasota at 70 day.

Experimental groups were reared under similar managerial and hygienic conditions. Fresh water was automatically available at all time by stainless steel nipples for each cage. The experimental diets were offered to the chicks ad libitum in mash form . At hatching day, the chicks were wing- banded, weighed and brooded on floor brooders with electric heaters were used for brooding chicks, at $32^{\circ} \mathrm{c}$ during the $1^{\text {st }}$ week and $3^{\circ} \mathrm{c}$ was decreased each week thereafter till it reached $22-24^{\circ} \mathrm{c}$. Wheat straw of $10 \mathrm{~cm}$ depth was used in brooding house. The wet litter was changed with dry one. Chicks were fed adlibitum on starting (23\% protein and $2900 \mathrm{Kcal} / \mathrm{kg}$ ) from 0 8 weeks and growing (18.5\% protein and $2850 \mathrm{Kcal} / \mathrm{kg}$ ) from 8-12 weeks.

\section{Studied traits:}

Chicks were individually weighed. Body weight was recorded at hatch, 4,8 and 12 weeks of age to the nearest $g$.

\section{Growth rate:}

Growth rate was estimated biweekly according to the equation of (Brody, 1945) during the period of hatch up to 12 weeks of age as (0- 4, 4 - 8 and 8- 12 wks).

\section{Gene Transferring response $(R)$ :}

Gene Transferring responses due to gene transfer in the second generation compared to the first generation

$\mathrm{R}_{\mathrm{t}}=\left(\mathrm{S}_{\mathrm{t}}-\mathrm{S}_{\mathrm{t}-1}\right)-\left(\mathrm{C}_{\mathrm{t}}-\mathrm{C}_{\mathrm{t}-1}\right)$.

Where: $R_{t}$ : realized gain due to transferring methods in $\mathrm{t}^{\text {th }}$ generation. 
$\mathrm{S}$ and $\mathrm{C}$ : average performance of the transferring methods and control populations (Becker, 1985).

\subsection{Genetic analyses:}

At the age 8 week of the experiment, 9 birds from each group in every generation were randomly chosen for collection of blood samples to genetic analyses.

\section{Random amplified cDNA ends (RACE) analysis of GH mRNA:}

The 5'RACE analysis was performed using a 5'/3'RACE kit (Roche, Sandhofer Strasse, Mannheim, Germany) according to the manufacturer's directions. Total RNA was prepared from blood using a GLASS MAX RNA Micro-isolation Spin Cartridge System (Life Technologies, Inc.), and $2 \mu \mathrm{g}$ of each total RNA were reverse transcribed using PE5R as reverse gene-specific primer and two forward gene-specific primers were used in subsequent amplification of cGH cDNA.

PCR amplification was conducted under the following conditions: $95^{\circ} \mathrm{C}$ for five minutes, followed by 30 to 35 cycles at $95^{\circ} \mathrm{C}$ for $45 \mathrm{~s}, 58^{\circ} \mathrm{C}$ to $68^{\circ} \mathrm{C}$ for 30 to $45 \mathrm{~s}$, and $72^{\circ} \mathrm{C}$ for 30 to $45 \mathrm{~s}$; followed by a final extension at $72^{\circ} \mathrm{C}$ for five minutes.

A 10 ul aliquot of each PCR reaction was electrophoresed on a $2.0 \%$ agarose gel, stained with ethidium bromide, and photographed under UV illumination. The amplified cDNA fragments were subcloned into a pGEM3Zf+ plasmid and subjected to sequencing. Sequence analysis was carried out using GENETYX software.

\subsection{Statistical analysis:}

Data were analyzed using SAS, 2004 software (SAS, 2004) by using two ways ANOVA to (methods of transferring and generation). The other symbols are as described previously. Differences were considered to be statistically significant at
$\mathrm{P}<0.05$. The difference among treatment were tested using Duncan's multiple range test at $\mathrm{P}<0.05$

Model 1:( BW.0 ,BW.4wks ,GR. 0-4 and GR. 4-8wks)

$\mathrm{X}_{\mathrm{ijk}}=\mu+\mathrm{M}_{\mathrm{i}}+\mathrm{G}_{\mathrm{j}}+\mathrm{MG}_{\mathrm{ij}}+\mathrm{e}_{\mathrm{ijk}}$

$X_{\mathrm{ijk}}=$ the observation of $\mathrm{ijk}$.

$\mu=$ overall mean.

$\mathrm{M}_{\mathrm{i}}=$ effect of the $\mathrm{i}^{\text {th }}$ methods of transferring $\mathrm{cGH}$ gene.

$\mathrm{G}_{\mathrm{j}}=$ effect of the $\mathrm{j}^{\text {th }}$ generation .

$\mathrm{MG}_{\mathrm{ij}}=$ the interaction between $\mathrm{M}_{\mathrm{i}}$ methods of transferring and $\mathrm{G}_{\mathrm{j}}$ generation eijk $=$ the experimental random error Model 2: :( BW.8,BW.12wks. and GR. 8-12wks)

$\mathrm{X}_{\mathrm{ijkl}}=\mu+\mathrm{M}_{\mathrm{i}}+\mathrm{G}_{\mathrm{j}}+\mathrm{S}_{\mathrm{k}}+\mathrm{MG}_{\mathrm{ij}}+\mathrm{MS}_{\mathrm{ik}}+\mathrm{GS}_{\mathrm{jk}}$ $+\mathrm{MGS}_{\mathrm{ijk}}+\mathrm{e}_{\mathrm{ijkl}}$

$\mathrm{X}_{\mathrm{ijk} \mathrm{l}}=$ the observation of $\mathrm{ijkl}$.

$\mu=$ overall mean.

$\mathrm{M}_{\mathrm{i}}=$ effect of the $i^{\text {th }}$ methods of transferring cGH gene.

$\mathrm{G}_{\mathrm{j}}=$ effect of the $\mathrm{j}^{\text {th }}$ generation .

$\mathrm{S}=$ effect of the $\mathrm{k}^{\text {th }}$ sex.

$\mathrm{MG}_{\mathrm{ij}}=$ the interaction between $\mathrm{i}^{\text {th }}$ methods of transferring and $j^{\text {th }}$ generation

$\mathrm{MS}_{\mathrm{ik}}=$ the interaction between $\mathrm{i}^{\text {th }}$ methods of transferring and $\mathrm{k}^{\text {th }}$ sex.

$\mathrm{GS}_{\mathrm{jk}}=$ the interaction between $\mathrm{j}^{\text {th }}$ generation and $\mathrm{k}^{\text {th }}$ sex.

$\mathrm{MGS}_{\mathrm{ijk}}=$ the interaction among $\mathrm{i}^{\text {th }}$ methods of transferring and $j^{\text {th }}$ generation as well as $\mathrm{k}^{\text {th }}$ sex.

$\mathrm{e}_{\mathrm{ijkl}}=$ the experimental random error

\section{RESULTS AND DISCUSSIONS}

Isolation, cloning and sequencing of (cGH) gene:

Total RNA was extracted from chicken liver tissue and the cDNA was successfully prepared. PCR amplification with $\mathrm{cGH}$ specific primers generated $429 \mathrm{bp}$ fragment .

The amplified cDNA fragments were then sub cloned into pGEM3Zf+ plasmid. Plasmid purification and perform stand- 
ard PCR shows a fragment of about 429bp when using specific cGH primers and the same fragment size was generated by double digestion of recombinant plasmid (Fig.1).

Finally the recombinant cDNA with the Gen Bank reference sequence accession number: LC441152.1 (Fig.2). The nucleotide and deduced amino acids were aligned and compared with reference sequence which showed about $99 \%$ matching due to heterozygous of the extracted cDNA. The result of this study is suggested an easy method to isolate and cloning of targeted varieties of chicken genes which may be useful to improve the local breed. Molecular biologists exploit the replicative ability of cultured cells to clone genes. Gene cloning also enables scientists to manipulate and study genes in isolation from the organism they came from. This allows researchers to conduct many experiments that would be impossible without cloned genes.

\section{Genetic analyses of GH mRNA}

The amplified cDNA fragments from blood sample of first and second generation were sub cloned into a pGEM3Zf+ plasmid and subjected to sequencing. Sequence analysis was carried out using GENETYX software. Showed that the PCR product size from mRNA was about 798 bp from Bandarah chicken control without any gene treatment, PCR Products Bandarah Growth Hormone GH, mRNA normal Length 800bp for Bandarah chicken by Bio method and PCR Products Bandarah Growth Hormone GH, mRNA Bandarah chicken by SMGT method. Figure 3,4 and 5showed that the changed in gene $\mathrm{GH}$ sequence between methods of gene transfer approved that gene $\mathrm{GH}$ which isolated from Cobb 500 was successfully transferred by two methods SMGT and BIO to Bandara chicken strain. The same sequence in each group in first and second generation showed that changed in $\mathrm{GH}$ gene as result of gene transferred by two methods SMGT and BIO was bass from parents to progeny

\section{Performance traits:}

Body weight at hatch (Bw 0) and four weeks (Bw 4) of age:

Means \pm SE for Bw 0 and Bw 4 of age as affected by methods and generations are shown in table (2). Body weight at hatch in the generation two was higher significantly than the first one. On the other hand, body weight at hatch for SGMT method had highest significant difference $\mathrm{P}<0.01$ weight when compared with that Bio and control one. The highest significant $(\mathrm{P}<0.01)$ value of $\mathrm{Bw} 4$ was found in SMGT method $176.47 \mathrm{~g}$ followed by the control one $170.64 \mathrm{~g}$ and the lowest value was found in bio method $168.82 \mathrm{~g}$, while there were no significant difference between the two generation for ( $\mathrm{Bw} 4)$ $177.77 \mathrm{~g}$ and $172.64 \mathrm{~g}$, respectively. The body weight at hatch and at 4 weeks of age increased by $3.32 \mathrm{~g}$ and 8.09 for SMGT method and by 1.27 and 5.22 for Bio method, respectively, Table (4).

\section{Body weight at 8 weeks of age (Bw 8):}

Table (3) shows the means \pm SE for body weight at eight weeks of age for males, females and combined sexes by methods and generations. The averages of the methods for these traits of the males were $386.98 \mathrm{~g}$ and $439.95 \mathrm{~g}$ for the first and second generation, respectively. The corresponding figures for the females were $326.76 \mathrm{~g}$ and $323.56 \mathrm{~g}$, respectively, while, the chick in the second generation had higher significantly $(\mathrm{P}<0.01)$ value $388.69 \mathrm{~g}$ than the first generation 351.29 g. Moreover, the highest insignificant body weight was found in SMGT method $372.05 \mathrm{~g}$. The differences between the 
overall mean of SMGT method and the control line were $56.72 \mathrm{~g}$ for males and $12.94 \mathrm{~g}$ for females, Table (4), while, the responses of Bio method were $-29.03 \mathrm{~g}$, and-101.13 $\mathrm{g}$ for male and female, respectively.

\section{Body weight at 12 wks of age:}

Means \pm SE of body weight at 12 weeks of age for males, females and combined sexes by methods and generations are presented in table (3).

The results show that, there were highly significant differences $(\mathrm{P}<0.01)$ between methods and generations for $\mathrm{Bw}$ at 12 wks of age. The second generation values were higher $(\mathrm{P}<0.01)$ than the first generation for males $814.31 \mathrm{~g}$ and $645.16 \mathrm{~g}$, respectively, followed by females 631.91 $\mathrm{g}$ and $533.72 \mathrm{~g}$, respectively. However, the SMGT method was the highest $(\mathrm{P}<0.01)$ weight 682.74 followed by Bio method $652.27 \mathrm{~g}$. the method of SMGT was increased the body weight at $12 \mathrm{wk}$ of age by $60.17 \mathrm{~g}$ and $7.96 \mathrm{~g}$ for males and females, respectively. Table (3) While, Bio method decreased body weight at 12 wks of age by $46.18 \mathrm{~g}$, and $71.01 \mathrm{~g}$ for males, females respectively table (4).

These results agree with (Al-Kelabil J. K. et al., 2019), Who found that cGH genes expression as for body weights, it has a favorable effect during the period of first four weeks, while its effect is limited after 6 weeks old. (Vasilatos-Younken et al. 1997) found that the chicken growth hormone $(\mathrm{cGH})$ gene is considered one of the most candidate genes that can influence chicken performance traits because of its crucial function in growth.

The chicken growth hormone $(\mathrm{cGH})$ gene plays a crucial role in controlling growth and metabolism, leading to potential correlations between $\mathrm{cGH}$ polymorphisms and economic traits.(Nie Q. et al., 2005).
(Yokoyama and Asahara 2011; Mohamed. 2009 and El-Tahawy. 2005) who all found that introducing foreign DNA into chicken embryonic cells significantly increased body weight of transgenic chicks.

Growth rate from day at hatch to four weeks of age:

Means and \pm SE of growth rate during (04) weeks of age by methods and generations are presented in table (5). The difference among methods was significant $(\mathrm{P}<0.05)$, and it was highly significant $(\mathrm{P}<0.01)$ between generations. However, the rate of growth for SMGT, Bio and control has 131.64\%, 130.68 and $132.35 \%$, respectively. The growth rate during (0-4) week of age decreased by $3.33 \%$ and $1.07 \%$ for SMGT and bio methods Table (4).

\section{Growth rate during (4-8) weeks of age}

Table (5) shows the means $\pm \mathrm{SE}$ of growth rate during (4-8) weeks of age by methods and generations. The chicks of the second generation had significantly higher value $76.62 \%$ than the first generation 68.51. While, it was no significant difference among methods. The Bio method had the highest growth rate at this period and the lowest one was found in control line. The growth rate during (4-8) week of age increased by $5.85 \%$ and 0.86 $\%$ for SMGT and bio methods Table (4).

Growth rate during (8-12) weeks of age

Table (6) presented the mean \pm SE of the growth rate during 8-12 weeks of age for males and females as affected by methods and generations. The second generation had higher growth rate at this period $(64.65 \%)$ than the first one $(49.94 \%)$. The difference among methods and generations were highly significant $(\mathrm{P}<0.01)$. For the methods, SMGT and Bio had approximately the same values, which were 
the highest growth rate (61.93 and $60.60 \%$ ), respectively. The SMGT and Bio methods increased growth rate during $(8-12)$ weeks of age by $5.03 \%$ and $10.72 \%$ for combined sex, respectively table (4).

These results agree that average growth rate increased by introducing foreign DNA the rate of increase was higher as foreign DNA level increased up to the level of $25 \mu \mathrm{g}$. However it decreased by increasing the level of foreign DNA to 30 $\mathrm{gg}$ (El-Garhy 2004; Deeb and Lamont 2002) stated that insulin-like growth factors, as molecular markers for growth rate in native breed. (Elokil, 2015) found that IGF-1 gene doses were highly significant effect $(\mathrm{P}<0.001)$ on growth rate $\%$ from hatch to 4 , GR from 4 to 8 , GR from 8 to 12, GR from 12 to 16 and GR from hatch to 16 weeks of age. $10 \mu \mathrm{g}$ IGF-1 gene was best dose in GR from hatch to 16 weeks with Mandarah (207.88\%) and 15 $\mu$ g IGF1 gene with Silver Montazah strain (201.54\%) compared to zero doses (194.81\%), respectively. (El-Garhy, 2011), Average growth rate increased by introducing foreign DNA the rate of increase was higher as foreign DNA level increased up to the level of $25 \mu \mathrm{g}$. However it decreased by increasing the level of foreign DNA to $30 \mu \mathrm{g}$.

\section{IN CONCLUSION}

cGH Gene successfully isolate, molecular cloning from Cobb 500, and transferring by two methods SMGT and Bio to production transgenic chickens of a local strain in Egypt Bandarah. The SMGT is an efficient method that will hopefully facilitate the implementation of strategies for securing the benefits that can be expected to arise from the introduction of transgenic chicken, Bio open important new perspectives in the field of animal transgenic would be more rapid, with quick and effective delivery of genes to target tissues. Chicken cGH gene was effect in growth performance and moved from the first generation to the second with the same shape and increased the effect 
Table (1): offspring number at hatch, 4,8 and 12 weeks of age of methods and two generations.

\begin{tabular}{|c|c|c|c|c|c|c|c|}
\hline \multirow{2}{*}{ Generation } & \multirow{2}{*}{$\begin{array}{c}\text { Methods of gene } \\
\text { transferring }\end{array}$} & \multicolumn{6}{|c|}{ Offspring Number } \\
\cline { 5 - 8 } & & $\begin{array}{c}\text { One } \\
\text { day }\end{array}$ & $\begin{array}{c}4 \\
\text { wk }\end{array}$ & \multicolumn{2}{|c|}{8 wk } & \multicolumn{2}{|c|}{12 wk } \\
\cline { 5 - 8 } & & 147 & 131 & 78 & 49 & 76 & 47 \\
One & SMGT & 139 & 135 & 54 & 78 & 53 & 75 \\
& Bio & 67 & 65 & 40 & 23 & 39 & 22 \\
\hline \multirow{2}{*}{ Two } & Control & 264 & 261 & 108 & 116 & 100 & 112 \\
& SMGT & 253 & 250 & 102 & 118 & 95 & 110 \\
& Bio & 108 & 100 & 50 & 36 & 47 & 34 \\
\hline
\end{tabular}

Table (2): Means \pm stander errors (SE) of body weight at hatch and four weeks of age by two methods of transferring techniques and generations of Bandarah strain

\begin{tabular}{|c|c|c|c|}
\hline \multirow[t]{2}{*}{ Generation } & \multirow{2}{*}{$\begin{array}{l}\text { Methods of } \\
\text { gene transfer- } \\
\text { ring }\end{array}$} & \multicolumn{2}{|c|}{ Body weight } \\
\hline & & Bw 0 & Bw 4 \\
\hline One & SMGT & $34.77 \pm 0.24$ & $174.23 \pm 3.51$ \\
\hline & Bio & $35.17 \pm 0.30$ & $168.45 \pm 2.92$ \\
\hline & Control & $35.10 \pm 0.42$ & $173.37 \pm 5.52$ \\
\hline Overall gen mean & & $34.99 \pm 0.17^{\mathrm{B}}$ & $171.77 \pm 2.14$ \\
\hline Two & SMGT & $36.68 \pm 0.18$ & $177.68 \pm 0.19$ \\
\hline & Bio & $35.03 \pm 0.19$ & $169.03 \pm 0.19$ \\
\hline & Control & $33.69 \pm 0.30$ & $168.73 \pm 0.32$ \\
\hline Overall gen mean & & $35.49 \pm 0.13^{\mathrm{A}}$ & $172.64 \pm 0.22$ \\
\hline Overall mth mean & SMGT & $36.00 \pm 0.15^{\mathrm{a}}$ & $176.47 \pm 1.24^{\mathrm{a}}$ \\
\hline & Bio & $35.08 \pm 0.16^{b}$ & $168.82 \pm 1.05^{b}$ \\
\hline & Control & $34.23 \pm 0.25^{c}$ & $170.64 \pm 2.27^{b}$ \\
\hline Factors & \multicolumn{3}{|c|}{ Significant } \\
\hline Generation (gen) & \multicolumn{2}{|c|}{$*$} & NS \\
\hline Methods (mth) & \multicolumn{2}{|c|}{$* *$} & $* *$ \\
\hline GenXmth & \multicolumn{2}{|c|}{$* *$} & NS \\
\hline
\end{tabular}

SMGT: sperm mediated gene transfer, Bio: Bioresonance method, gen: generation, mth: method, BW 0 body weight at hatch, Bw 4 body weghit at four weeks of age, NS: non-significant ,* Significant at $\leq 0.05, * *$ Significant at $\leq 0.001,{ }^{a}, \mathrm{~b}, \mathrm{c}$ Means within the same column in the same trait with different superscripts are significantly different $(\mathrm{P} \leq 0.05)$. 
W. S. EL-Tahawy et al.

Table (3): Means \pm stander errors (SE) of body weight at eight and twelve weeks of age for male and female by two methods of transferring techniques and generations of Bandarah strain.

\begin{tabular}{|c|c|c|c|c|c|c|c|}
\hline \multirow[t]{2}{*}{ Generation } & \multirow{2}{*}{$\begin{array}{l}\text { Methods of } \\
\text { gene trans- } \\
\text { ferring }\end{array}$} & \multicolumn{3}{|c|}{ Body weight at $8 \mathrm{wk}$} & \multicolumn{3}{|c|}{ Body weight at 12 wk } \\
\hline & & Male & Female & $\begin{array}{c}\text { Combined } \\
\text { sex }\end{array}$ & Male & Female & $\begin{array}{c}\text { Combined } \\
\text { sex }\end{array}$ \\
\hline \multirow[t]{5}{*}{ One } & SMGT & $\begin{array}{c}368.34 \pm \\
12.72\end{array}$ & $\begin{array}{c}328.11 \pm \\
8.08\end{array}$ & $\begin{array}{c}343.87 \pm \\
7.16\end{array}$ & $\begin{array}{c}645.61 \pm \\
12.76\end{array}$ & $\begin{array}{c}567.77 \pm \\
10.62\end{array}$ & $\begin{array}{c}598.90 \pm \\
8.78\end{array}$ \\
\hline & Bio & $379.32 \pm$ & $332.42 \pm$ & $352.99 \pm$ & $660.71 \pm$ & $524.67 \pm$ & $586.86 \pm$ \\
\hline & & 10.52 & 7.78 & 6.69 & 14.67 & 11.43 & 11.26 \\
\hline & Control & $441.85 \pm$ & $315.05 \pm$ & $364.25 \pm$ & $615.54 \pm$ & $477.68 \pm$ & $531.98 \pm$ \\
\hline & & 16.79 & 16.02 & 13.95 & 21.50 & 16.81 & 15.57 \\
\hline $\begin{array}{l}\text { Overall gen } \\
\text { mean }\end{array}$ & & $\begin{array}{c}386.98 \pm \\
7.80^{\mathrm{B}}\end{array}$ & $\begin{array}{c}326.76 \pm \\
5.63\end{array}$ & $\begin{array}{c}351.29 \pm \\
4.89^{\mathrm{B}}\end{array}$ & $\begin{array}{c}645.16 \pm \\
8.90\end{array}$ & $\begin{array}{c}533.72 \pm \\
7.59\end{array}$ & $\begin{array}{r}580.34 \pm \\
6.57^{\mathbf{B}}\end{array}$ \\
\hline \multirow[t]{5}{*}{ Two } & SMGT & $\begin{array}{c}480.79 \pm \\
10.41\end{array}$ & $\begin{array}{c}336.83 \pm \\
6.99\end{array}$ & $\begin{array}{c}401.04 \pm \\
8.45\end{array}$ & $\begin{array}{c}873.13 \pm \\
10.69\end{array}$ & $\begin{array}{c}678.82 \pm \\
7.63\end{array}$ & $\begin{array}{c}743.59 \pm \\
9.15\end{array}$ \\
\hline & Bio & $406.02 \pm$ & $252.95 \pm$ & $378.31 \pm$ & $781.88 \pm$ & $556.75 \pm$ & $697.46 \pm$ \\
\hline & & 7.34 & 9.76 & 8.32 & 9.89 & 9.85 & 11.41 \\
\hline & Control & $497.58 \pm$ & $336.71 \pm$ & $377.79 \pm$ & $782.89 \pm$ & $580.77 \pm$ & $656.56 \pm$ \\
\hline & & 14.19 & 10.01 & 13.21 & 24.21 & 19.15 & 20.60 \\
\hline \multirow{2}{*}{$\begin{array}{c}\text { Overall gen } \\
\text { mean }\end{array}$} & & $439.95 \pm$ & $323.56 \pm$ & $388.69 \pm$ & $814.31 \pm$ & $631.91 \pm$ & $714.60 \pm$ \\
\hline & & $6.42^{\mathrm{A}}$ & 5.49 & $5.46^{\mathrm{A}}$ & 7.73 & 7.03 & $6.96^{\mathrm{A}}$ \\
\hline \multirow{8}{*}{$\begin{array}{c}\text { Overall } \\
\text { mean }\end{array}$} & SMGT & $427.42 \pm$ & $332.12 \pm$ & 372.05 & 767.22 & $634.94 \pm$ & $682.74 \pm$ \\
\hline & & 9.63 & 5.25 & \pm 5.77 & \pm 13.39 & 7.29 & $7.59^{\mathrm{a}}$ \\
\hline & Bio & $396.81 \pm$ & $312.79 \pm$ & 365.76 & 741.21 & 540.71 & $652.27 \pm$ \\
\hline & & 6.10 & 7.33 & \pm 5.40 & \pm 9.49 & \pm 7.66 & $8.83^{\mathbf{b}}$ \\
\hline & Control & $459.45 \pm$ & $325.03 \pm$ & 369.83 & 684.00 & 521.86 & $584.44 \pm$ \\
\hline & & 12.94 & 9.82 & \pm 9.82 & \pm 20.88 & \pm 13.96 & $13.73^{\mathrm{c}}$ \\
\hline & Sex & $416.72 \pm 5.19$ & $325.45 \pm$ & & $742.86 \pm$ & 586.98 & \\
\hline & & $\mathrm{A}$ & $4.01^{\mathrm{B}}$ & & $7.55^{\mathrm{A}}$ & $\pm 5.72^{\mathrm{B}}$ & \\
\hline \multicolumn{2}{|c|}{ Factors } & \multicolumn{6}{|c|}{ Significant } \\
\hline \multirow{2}{*}{\multicolumn{2}{|c|}{$\begin{array}{l}\text { Generation (gen) } \\
\text { Methods (mth) }\end{array}$}} & \multicolumn{3}{|c|}{$* *$} & \multicolumn{3}{|c|}{$* *$} \\
\hline & & \multicolumn{3}{|c|}{ NS } & \multicolumn{3}{|c|}{$* *$} \\
\hline & \multicolumn{3}{|c|}{$* *$} & \multicolumn{3}{|c|}{$* *$} \\
\hline \multicolumn{2}{|c|}{ GenXmth } & & \multicolumn{3}{|c|}{ NS } \\
\hline \multirow{2}{*}{\multicolumn{2}{|c|}{$\begin{array}{l}\text { GenXsex } \\
\text { mthXsex }\end{array}$}} & \multicolumn{3}{|c|}{$* *$} & \multicolumn{3}{|c|}{ NS } \\
\hline & & \multirow{2}{*}{\multicolumn{3}{|c|}{$\begin{array}{l}* * \\
* *\end{array}$}} & & $* *$ & \\
\hline \multicolumn{2}{|c|}{$\begin{array}{c}\text { mthXsex } \\
\text { GenXmthXsex }\end{array}$} & & & & \multicolumn{3}{|c|}{$* *$} \\
\hline
\end{tabular}

SMGT: sperm mediated gene transfer, Bio: Bioresonance method, gen: generation, mth: method, NS: non-significant, ${ }^{*}$ Significant at $\leq 0.05$, ** Significant at $\leq 0.001,{ }^{a, b, c}$ Means within the same column in the same trait with different superscripts are significantly different $(\mathrm{P} \leq 0.05)$. 
Local chicken, cGH gene, Gene transfer, SMGT, Growth traits

Table (4): Response of two methods of gene transferring for body weight at hatch, four week, eight week, twelve week of age and growth rate during the period( 0:4, 4:8, 8:12 weeks) of age.

\begin{tabular}{|l|c|c|c|}
\hline \multicolumn{1}{|c|}{ Methods } & SEX & SMGT & Bio \\
\hline Body weight at hatch & & 3.32 & 1.27 \\
Body weight at four weeks & & 8.09 & 5.22 \\
\hline \multirow{3}{*}{ Body weight at eight weeks } & Male & 56.72 & -29.03 \\
& Female & -12.94 & -101.13 \\
& combined sexes & 43.63 & 11.78 \\
\hline \multirow{3}{*}{ Body weight at twelve weeks } & Male & 60.17 & -46.18 \\
& Female & 7.96 & -71.01 \\
& combined sexes & 20.11 & -13.98 \\
\hline Growth rate 0: 4 & & -3.33 & -1.07 \\
Growth rate 4: 8 & & 5.85 & 0.86 \\
\hline \multirow{3}{*}{ Growth rate 8:12 } & Male & -9.67 & -0.84 \\
& Female & 16.79 & 34.93 \\
& combined sexes & 5.03 & 10.72 \\
\hline
\end{tabular}

SMGT: sperm mediated gene transfer, Bio: Bioresonance method

Table (5): Means \pm stander errors (SE) of growth rate from day of hatch to four weeks of age and from four to eight weeks of age by two methods of transferring techniques and generations for Bandarah strain

\begin{tabular}{|c|c|c|c|}
\hline \multirow[t]{2}{*}{ Generation } & \multirow{2}{*}{$\begin{array}{l}\text { Methods of gene } \\
\text { transferring }\end{array}$} & \multicolumn{2}{|c|}{ Growth rate } \\
\hline & & $0: 4$ & $4: 8$ \\
\hline One & $\begin{array}{l}\text { SMGT } \\
\text { Bio } \\
\text { Control }\end{array}$ & $\begin{array}{l}131.62 \pm 1.04 \\
129.16 \pm 1.11 \\
130.27 \pm 1.33 \\
\end{array}$ & $\begin{array}{l}66.29 \pm 1.16 \\
70.89 \pm 1.65 \\
69.25 \pm 0.93\end{array}$ \\
\hline Overall gen mean & & $130.35 \pm 0.66^{\mathrm{B}}$ & $68.51 \pm 0.77^{B}$ \\
\hline Two & $\begin{array}{l}\text { SMGT } \\
\text { Bio } \\
\text { Control }\end{array}$ & $\begin{array}{l}131.65 \pm 0.22 \\
131.45 \pm 0.24 \\
133.63 \pm 0.40\end{array}$ & $\begin{array}{l}77.25 \pm 1.48 \\
76.86 \pm 1.47 \\
74.36 \pm 2.71\end{array}$ \\
\hline Overall gen mean & & $131.91 \pm 0.16^{\mathrm{A}}$ & $76.62 \pm 0.98^{A}$ \\
\hline over all mean & $\begin{array}{l}\text { SMGT } \\
\text { Bio } \\
\text { Control }\end{array}$ & $\begin{array}{l}131.64 \pm 0.37^{\mathrm{ab}} \\
130.68 \pm 0.41^{\mathrm{b}} \\
132.35 \pm 0.57^{\mathrm{a}}\end{array}$ & $\begin{array}{l}71.93 \pm 1.01 \\
74.14 \pm 1.12 \\
71.30 \pm 1.24\end{array}$ \\
\hline factors & \multicolumn{3}{|c|}{ Significant } \\
\hline $\begin{array}{c}\text { Generation (gen) } \\
\text { Methods (mth) } \\
\text { GenXmth }\end{array}$ & $\begin{array}{l}* * \\
* \\
*\end{array}$ & & $\begin{array}{l}* * \\
\text { NS } \\
\text { NS }\end{array}$ \\
\hline
\end{tabular}

SMGT: sperm mediated gene transfer, Bio: Bioresonance method, gen: generation, mth: meth-

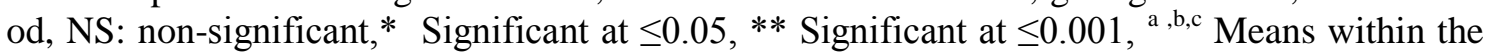
same column in the same trait with different superscripts are significantly different $(\mathrm{P} \leq 0.05)$. 
Table (6): Means \pm stander errors (SE) of growth rate during 8:12 weeks of age for male and female by two methods of transferring techniques and generations of Bandarah strain

\begin{tabular}{|c|c|c|c|c|}
\hline \multirow[t]{2}{*}{ Generation } & \multirow{2}{*}{$\begin{array}{l}\text { Methods of } \\
\text { gene transfer- } \\
\text { ring }\end{array}$} & \multicolumn{2}{|c|}{ Growth rate 8:12 wk } & \multirow[b]{2}{*}{$\begin{array}{c}\text { Combined } \\
\text { sex }\end{array}$} \\
\hline & & Male & Female & \\
\hline \multirow[t]{3}{*}{ one } & SMGT & $55.10 \pm 2.86$ & $55.61 \pm 2.04$ & $55.40 \pm 1.67$ \\
\hline & Bio & $52.28 \pm 2.93$ & $47.25 \pm 2.02$ & $49.80 \pm 1.80$ \\
\hline & Control & $32.99 \pm 0.83$ & $44.23 \pm 2.45$ & $39.58 \pm 1.64$ \\
\hline Overall gen mean & & $49.17 \pm 1.80$ & $50.54 \pm 1.34$ & $49.94 \pm 1.09^{\mathrm{B}}$ \\
\hline \multirow[t]{3}{*}{ two } & SMGT & $57.92 \pm 0.93$ & $75.40 \pm 1.07$ & $67.69 \pm 1.06$ \\
\hline & Bio & $63.93 \pm 0.53$ & $85.18 \pm 2.61$ & $67.78 \pm 0.99$ \\
\hline & Control & $45.48 \pm 1.74$ & $47.23 \pm 1.49$ & $46.84 \pm 1.17$ \\
\hline Overall gen mean & & $60.54 \pm 0.60$ & $70.15 \pm 1.50$ & $64.65 \pm 0.78^{A}$ \\
\hline \multirow[t]{4}{*}{ Overall } & SMGT & $56.66 \pm 1.37$ & $65.79 \pm 1.41$ & $61.93 \pm 1.04^{\mathrm{a}}$ \\
\hline & Bio & $60.54 \pm 1.03$ & $60.75 \pm 2.86$ & $60.60 \pm 1.13^{\mathrm{a}}$ \\
\hline & Control & $37.27 \pm 1.29$ & $45.64 \pm 1.48$ & $42.63 \pm 1.13^{b}$ \\
\hline & Sex & $56.00 \pm 0.87^{\mathrm{B}}$ & $59.71 \pm 1.17^{\mathrm{A}}$ & \\
\hline factors & \multicolumn{4}{|c|}{ Significant } \\
\hline Generation (gen) & \multicolumn{4}{|c|}{$* *$} \\
\hline Methods (mth) & \multicolumn{4}{|c|}{$* *$} \\
\hline Sex & \multicolumn{4}{|c|}{$* *$} \\
\hline GenXmth & \multicolumn{4}{|c|}{ NS } \\
\hline GenXsex & \multicolumn{4}{|c|}{$* *$} \\
\hline mthXsex & \multicolumn{4}{|c|}{$* *$} \\
\hline GenXmthXsex & \multicolumn{4}{|c|}{$* *$} \\
\hline
\end{tabular}

SMGT: sperm mediated gene transfer, Bio: Bioresonance method, gen :generation, mth: methods, NS: non-significant, ${ }^{*}$ Significant at $\leq 0.05,{ }^{* *}$ Significant at $\leq 0.001,{ }^{a}, b, c$ Means within the same column in the same trait with different superscripts are significantly different $(\mathrm{P} \leq 0.05)$. 
Local chicken, cGH gene, Gene transfer, SMGT, Growth traits

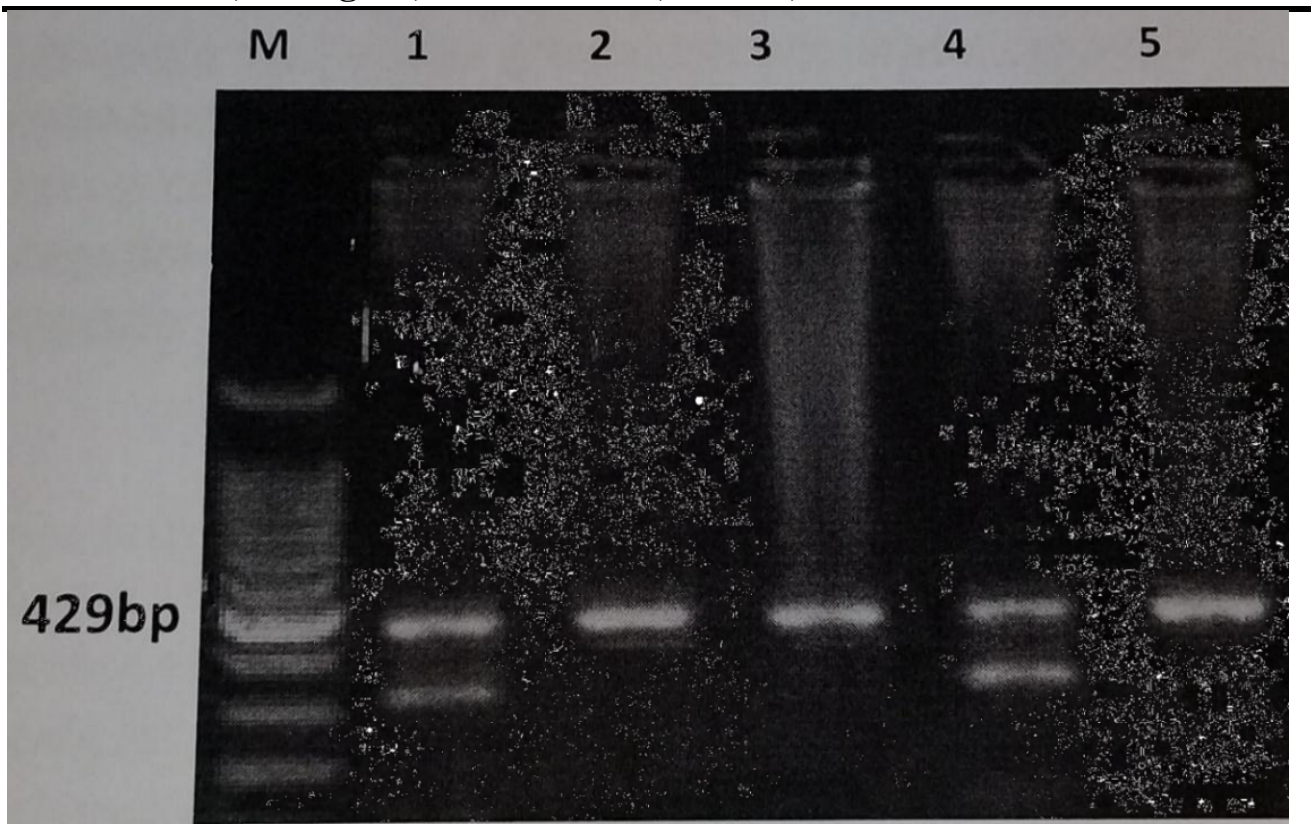

Fig(1):Agarose gel electrophoresis (1.5\%) of PCR products using GH forward (F) and $\mathrm{GH}$ reverse (R) primers using cDNA as a template. M: 100 bp DNA Ladder from Cobb broiler

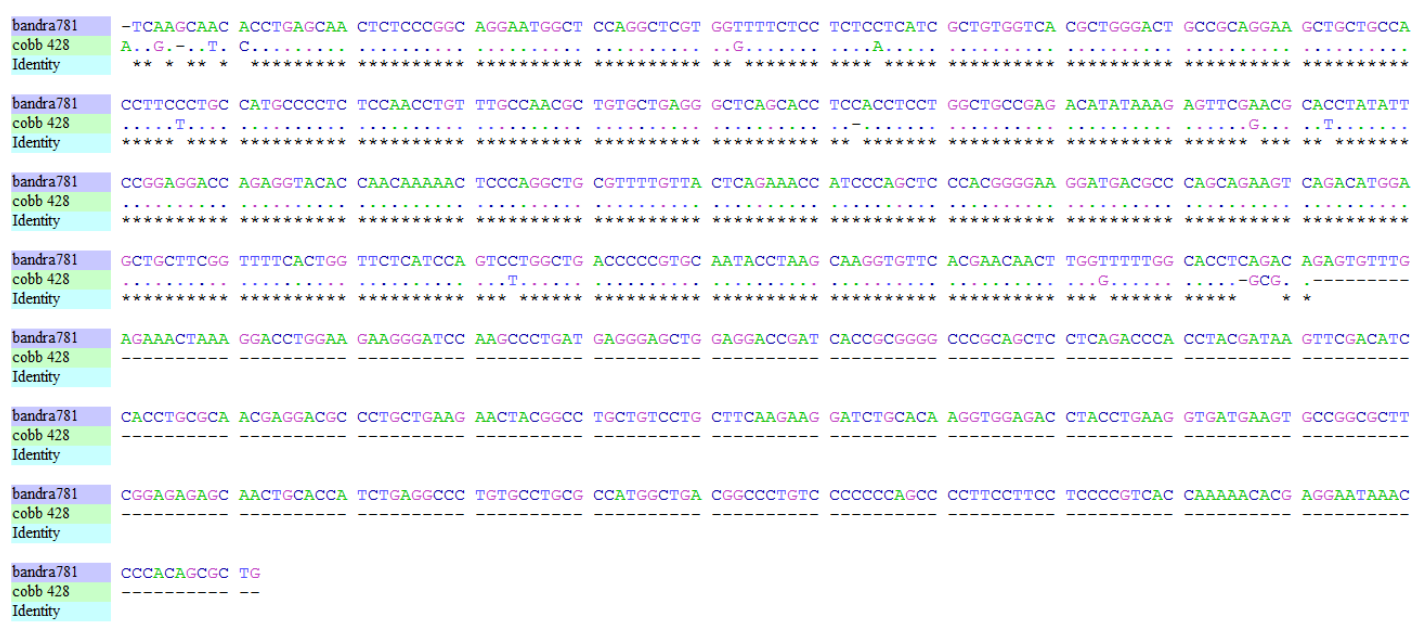

Fig(2):Sequencing alignment result of cGH recombinant gene by standard Sanger sequencing method using T7 forward primer. 


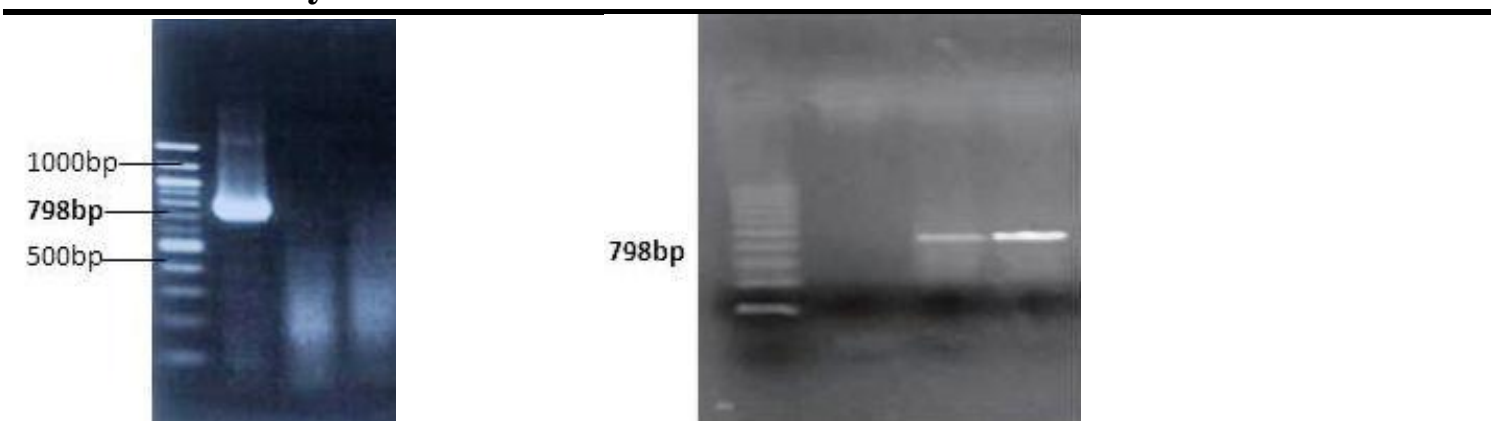

Fig (3): PCR Products Bandarah Growth Hormone GH, mRNA Length 798bp, for Bandarah chicken control without any gene treatment of first and second generation
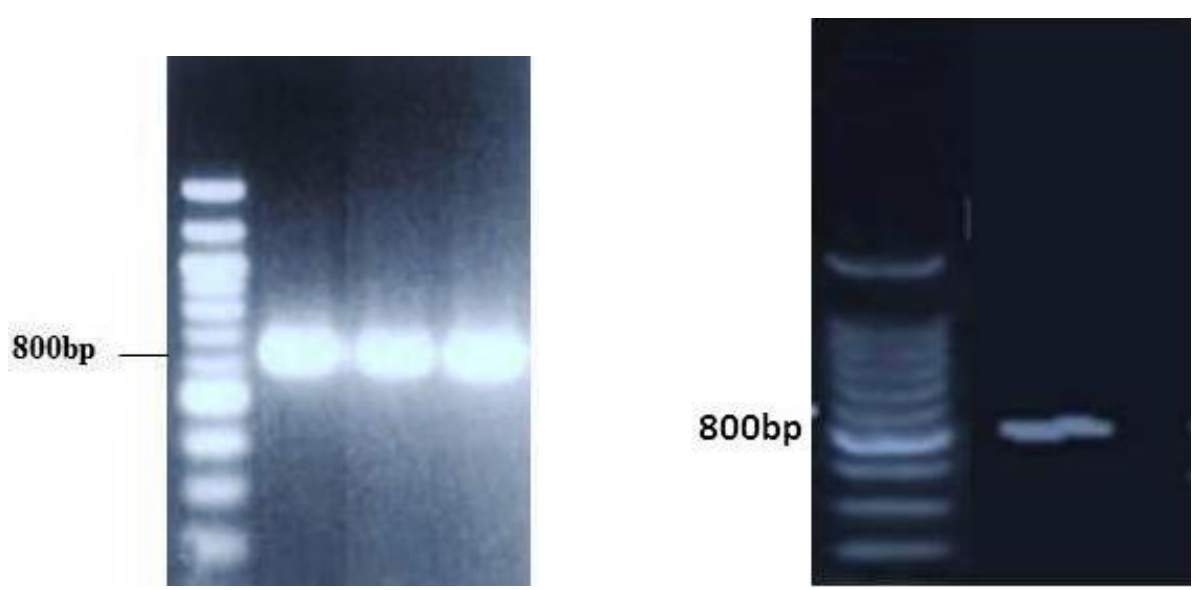

Fig (4): PCR Products Bandarah Growth Hormone GH, mRNA normal Length 800bp, from Bandarah chicken by Bio method of first and second generation
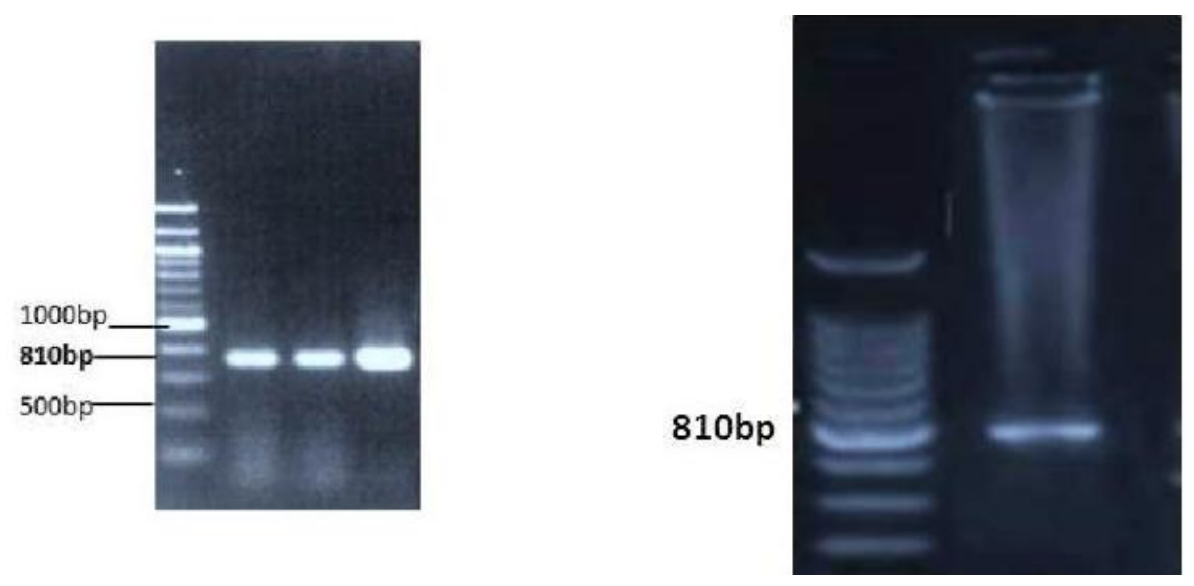

Fig (5): PCR Products Bandarah Growth Hormone GH, mRNA Bandarah chicken by SMGT method first and second generation. 


\section{REFERENCES}

Al-Kelabil J. K., Mayada F. Mohamed, Mohammed R., AL-Karagoly, H.. 2019. Growth hormone and growth hormone receptor genes expression related with productive traits of broilers under the effectiveness of the sweet basil plant additive as a growth promoter. Adv. Anim. Vet. Sci. 7(5): 361369.

DO

http://dx.doi.org/10.17582/journal.aavs 12019/7.5.361.369. ISSN (Online) 2307-8316; ISSN (Print) | 2309-3331.

Bahrami S., Yekta A., Daneshipour

A., Jazayeri S., Mozdziak P., Sanati M. and Gourabi H. 2020. Designing a transgenic chicken: Applying new approaches toward a promising bioreactor. Cell Journal V.22:133-139.

Becker. 1985. Manual al proceluyeo in qutantitatire geneticy Vash. State, berero, plama, Washington.

Brody, S. 1945. Bioenergetics and growth. Reinhold Pub. Corp., N. Y.

Challagulla A., Jenkins K., Oneil T., Morris K., Wise T. AND Tizard M. 2020. Germline engineering of the chicken genome using CRISPR/ Caseq by in vivo transfection of PGCS. Animal

Biotechnology. https://doi.Org/10.1080/10495398.202 0.1789869 .

Deeb, N. and Lamont, S. J. 2002. Genetic architecture of growth and body composition in unique chicken populations. J. Hered. 93:107-118.

EL-Garhy, O. H. M 2004. Effect of some biotechnological methodology on some productive and reproductive traits in fowl. M.Sc. Thesis, Fac. of Agric., Moshtohor, Zagazig Univ. Benha Branch,Egypt.

EL-Garhy, O. H. M. 2011. Study of the effect of genetical factors using genetic engineering technology with rela- tion to some metabolic and productive traits in fowl. Ph.D Thesis, Fac. of Agric., Benha Univ, Egypt.

ELokil A. A. 2015. Applicability of the modern biological technology for improving the productive performance of some local poultry breeds. Ph.D Thesis,Fac. of Agric. Benha Univ. Egypt.

EL-Tahawy, W. S. 2005. Production of transgenic local chicken by injection of DNA from Japanese quails or broiler breeds. Ph.D Thesis, Fac. of Agric. Damanhour Branch, Alex. Univ. Egypt.

Hrabia, A., Paczoska- ELiasiewicz H. E., Berghhman L. R., HARVEY S., and Rzasa.J. 2008. Expression and localization of growth hormone and its receptors in the chicken ovary during sexual maturation. Cell Tissue Res. 332:317-328.

Kansaku N, Hiyama G, Sasnami T and Zadwony D. 2008. Prolactin and growth hormone in birds: Protein structure, gene structure and genetic variation. Journal of Poultry Science, 45: 1-6.

Kim, J. H.; Jungha, H. S. and Lee, H. T. 1997. Development of a positive method for male stem cell-mediated gene transfer in mouse and pig. Mol. Reprod. Dev., 46: 515-526.

Lauria, A. and Ganolfi, F. 1993. Recent advances in sperm cell mediated gene transfer.Mol. Reprod. Dev., 36: 255-257

Li, J.J. and Lu L.Z . 2010.Recent progress on the technologies and applications of transgenic poultry.Afr. J. Biotechnol. 9: 3481-3488.

Mahmoud, T.H.; J.E. Abd EL-Hamid and A.I. EL-Turkey. 1989. "Bandara" A new breed of chickens. Agric. Res. Rev., 67:229. 
Mcmurtry, J. P, Francis, G. L. and Upton, Z. 1997. Insulin-like growth factors in poultry. Domestic Animal Endocrine 14: 199-229.

Mcmurtry, J. P. 1998. Nutritional and developmental roles of insulin-like growth factors in poultry. J. Nutrition 1(28):302-310.

Mohamed, A.F. 2009. Effect of recent biotechnological technique on broiler hybrid chickens production. Ph.D. Thesis, Fac. of Agric. (Saba-basha), Alex. Univ. Egypt.

Mohamed E; Sobokhi SH; Maryam S; Larysia CH. 2015 . An Introduction to Impact of Bio-Resonance Technology in Genetics and Epigenetics. Epigenetics Territory and Cancer. Chapter IV. 495-513. https://www.researchgate.net/publicati on/292162844.

Nie Q., Sun B., Zhang D., Luo C., Ishag N. A., Lei M., Yang G., and Zhang, X. 2005. High diversity of the chicken growth hormone gene and effects on growth and carcass traits. Journal of Heredity 96(6):698-703.

Promwatee, N., B. Laopaiboon, T. Vongpralub, Y. Phsuk, S. Kunhareang, W. Boonkum, and $M$. Duangjinda. 2013. Insulin-like growth factor I gene polymorphism associated with growth and carcass traits in Thai synthetic chickens. Genet. Mol. Res. 12:4332-4341.

Sas. 2004. Sas procedure guide version 6.12thed., Sas Institute Ine., CaryY, NC, USA.

Spadafora, C. 2002. Spermmdiated gene transfer: Practical implications of biologoical process. Transgenic Res., 11:82-83.

Vasilatos Y R, dunnington E A, Silegel, P. B. and Mcmurtry, J P. 1997. Tissue-specific alterations in insulin- like growth factor-1 concentrations in response to 3, 3, 5-triiod L-thyronine supplementation in the growth hormone receptor-deficient sexlinked dwarf chicken. General Comparative Endocrinology 6: 105.

World Health Orgnization "WHO". 2015. Electromagnetic fields. Health topics. https://www.who.int/healthtopics/electromagneticfields\#tab=tab_1.

Yokoyama, S. and Asahara, H. 2011. The myogenic transcriptional network. CellMol Life Sci. 68: 1843-1849.

Zhou, H.; Mitchell, A. D., Mcmutry, J. P., Ashwell, C. M, and Lamont, S. J. 2005. Insulin-like growth factor-I Gene polymorphism associations with growth, body composition, skeleton integrity, and metabolic traits inchickens. Poultry Sci. 84: 212-219. 


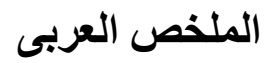

التحسين الوراثي لبعض الصفات الانتاجيه للاجاج المحلي المصري عن طريق نقل جين هرمون النمو من بلاري التسمين

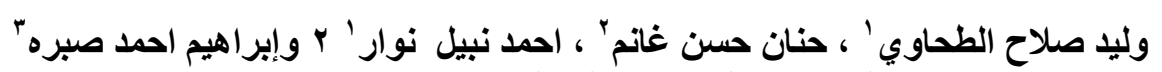

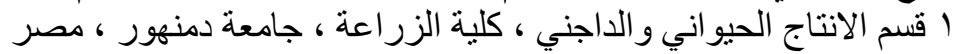

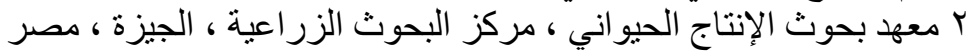

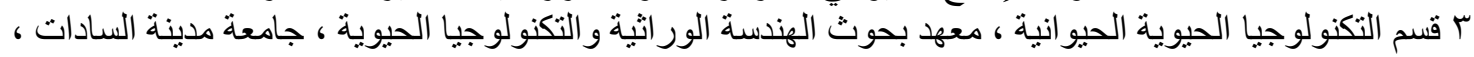

مصر

كان الهدف من الدراسه هو عزل واستنساخ ومعرفه تتابع القو اعد النيتروجينيه وتسلسل جين هرمون نمو الدجاج

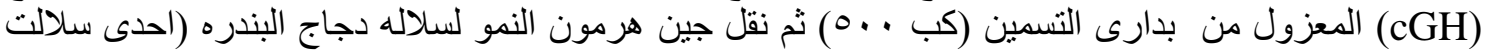

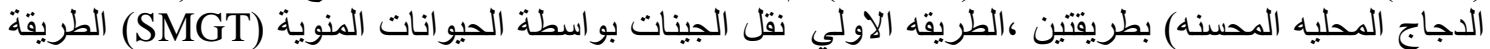

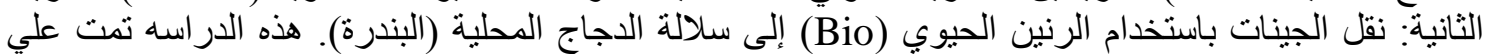

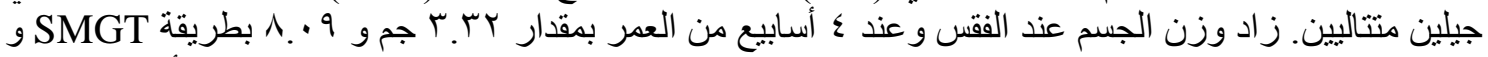

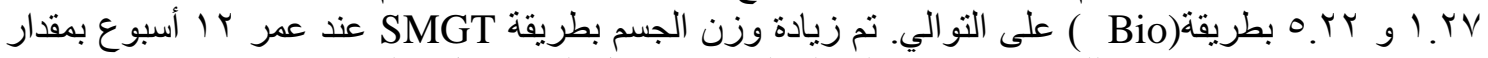

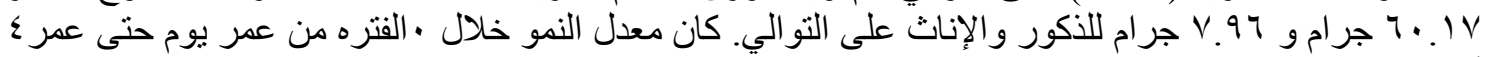

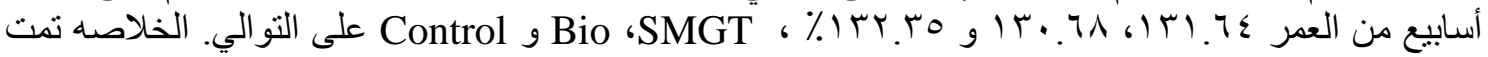

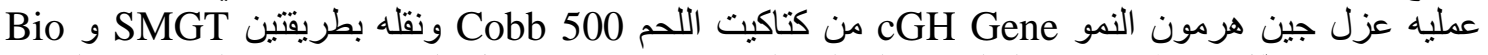

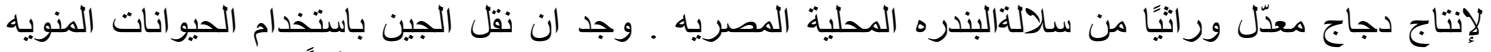

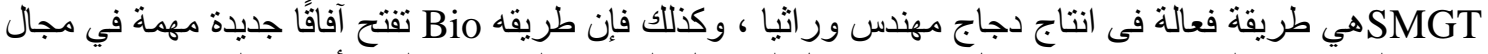

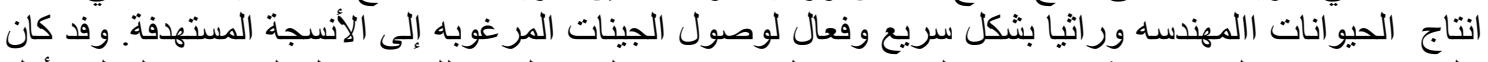

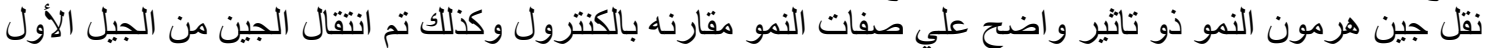

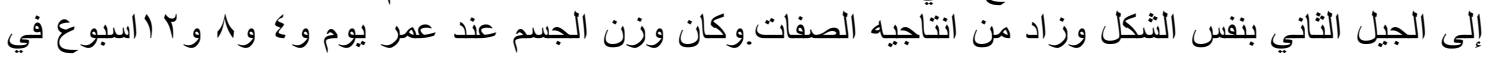

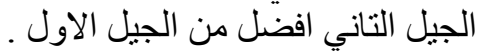

الكلمات الداله: الدجاج المحلي ، جين هرمون النمو cGH ، نقل الجينات ، SMGT ، صفات النمو 